\title{
THE PROTESTANT WORK ETHIC, THE SPIRIT OF ENTERPRISE AND THE SIEGERLAND MENTALITY ।
}

\author{
Bodo B. Gemper \\ Department of Economics \\ University of Siegen \\ WEST GERMANY
}

\section{INTRODUCTION}

We know that our intellectual heritage influences our approach to modern economic and social issues. Nevertheless, the history of economic thought and of political economy which forms the basis for research into the grassroots of socio-cultural development are currently outside the confines of mainstream economic analysis. Consequently, many of the results of research carried out nowadays are, unfortunate $y$, more likely to resemble a pamphlet on mathematical econophysics than an economic treatise. However, cultural evolution only enables us to conceive that "all the major schools of thought in economics have concomitant types of social organization. ... Substantively, what expresses growth and development in the dynamics of economic evolution is culture" (Brinkman, 1981:xii).

Examples of the aspects which are being badly neglected, are cultural economics in general and the origins of Western economic civilization and industrial culture in particular. The Protestant work ethic in this context belongs to the central features, which are primarily a subject of the Protestant ethic. The latter is relevant when related to the economic order in the form of a free market economy. But one question remains: What does capitalism in this context mean nowadays? Moreover, can social market economy be put in its proper place? Without any doubt there is a logical connection between the Protestant work ethic, the spirit of enterprise, the social market economy and federalism.

\footnotetext{
${ }^{1}$ Originally presented as a lecture on the occasion of the 70th anniversary of the Faculty of Economic and Management Sciences, the Department of Economics of the University of Pretoria.
} 
The the Protestant work ethic and the social market economy are closely linked, just as the social market economy and the federalism are complementary to each other. This is the reason why I not only take the central aspect of the work ethic into consideration, but the market principle and the federal principle as well. One should not forget that both the social market economy and federalism have been quite successful in West Germany and they could be a concept forming part of the strategic orientation within the efforts at reform in your country.

The relationship between the Protestant ethic and socio-economic life forms the platform from which the Siegerland mentality can be examined as it is a special example of the spirit of capitalism which is moreover not only unique, but also still alive in the region of Germany which is called the Siegerland. The Siegerland mentality is really a unique feature of the ways of life, typical for the region, called Siegerland, named after the biggest town in this region, Siegen, which has about 120000 inhabitants. It is not only the considerable size of this region that is characteristic, but also the fact that this mentality, determined by the Protestant ethic, is still alive in this central part of West Germany. It is a well-preserved economic industrial region, comprising mainly the iron and steel industries.

\section{THE PROTESTANT ETHIC AND THE SPIRIT OF CAPITALISM}

The purpose of my lecture is to demonstrate that the origin of the basic economic attitudes, or perhaps it is better to say the economic spirit, the ethos of the economic system, is conditioned on doctrines of faith. The economic spirit in general is based on two constitutive elements: firstly on the idea of the invisible hand, which refers to the free market mechanism and secondly, on Protestant religious thinking.

The particular prevailing Protestant ethic, for example the Lutheran or Calvinistic religious school, characterizes concrete sentiments towards work and business in a society. Beginning in the Middle Ages, more and more people in central Europe reasoned that the development of man and the evolution of mankind revolved around work, making an effort and doing things which are useful or necessary, rather than relaxing or doing things purely for enjoyment - in other words - hard work is beneficial for you.

Considerable research has been carried out in Germany by Max Weber on the Protestant work ethic within his fundamental work on The Protestant ethic and the spirit of 
capitalism, between 1904 and 1920. His research undoubtedly ranks foremost among the scientific studies which attempt to explain the secret of economic efficiency and the durability of capitalism based on the reliable work of the invisible hand. Moreover, Max Weber's theses, of course, belong to the most stimulating, yet very controversial subjects in modern social science. Since this is my sixth visit to South Africa to teach economics in your country, and my third to your university, I am aware that the universities here impart considerable knowledge and thus most of the academics and students will be familiar with the scientific work of Max Weber.

In this lecture I focus my interest on a special aspect which forms a keystone of the Protestant ethic, namely the Protestant work ethic. Moreover, attention is asked for an issue which will probably provide some new information about what is meant by the Siegerland mentality, which is of intrinsic value for the spirit of capitalism.

Philosophers like Karl Marx, social scientists like Max Weber and historians doing research in the field of the history of economic thought and economic history, have long been attracted by the fact that some countries are particularly successful. Why, for example, are the USA and West-Germany pace-makers, while neighbouring countries sometimes, in comparison, resemble developing countries?

Why is South Africa a powerful economic community despite the pressure from abroad and even though it has a dual economy? "How can advanced countries produce so much more output with so much less sweat than do poor countries" (Samuelson \& Nordhaus, 1985:823). This definition of the problem, pointed out by Paul Anthony Samuelson, is exactly the crucial question.

In the very early stage of economic thinking, theorists based their concepts on aspects of the natural environment, such as climate, noting that most of the advanced countries are located in temperate zones of climate. In more advanced concepts, customs were regarded as the sensible basis for research and last but not least it became evident that culture, especially religion, is a key evolutionary factor which has promoted new developments and changes in society. This means that culture is the decisive factor for improving conditions in social life or for creating a more sophisticated way of life.

A most important key for understanding the 'secret' of cultural development is the Protestant ethic. This means that social and economic progress is partly a function of the vitality of people, inspired by the Protestant ethic, by which the lifestyle in a country is stimulated. The Protestant ethic gets a hold on the people of a region by influencing their mental (personal) attitudes, to work, and while quite a number of 
attitudes normally are subject to change, there are some areas which are particularly subject to change and there are also others with very little change in attitudes at all.

The Protestant work ethic is a motive force which promotes the progress of Western civilization. This means that the way to success is by way of a traditional virtue and by accepting certain principles of religion. The Protestant work ethic especially is such a motive force in driving people to seek personal gain. What does this really mean?

Strictly speaking, the Protestant work ethic is a moral belief that inevitably influences the behaviour patterns, the attitudes and the philosophy of life of people. In the words of Max Weber (1985:26) this is a question of a specific "rationalism of Western culture".

It is hence our first concern now to work out and to explain the special peculiarity of Occidental rationalism, and within this context that of the development of rational economic conduct.

Every such attempt at explanation must, recognizing the fundamental importance of the economic factor, above all take account of the cconomic conditions. But at the same time the opposite correlation must not be left out of consideration. For though the development of economic rationalism is partly dependent on rational technique and law, it is at the same time determined by the ability and disposition of men to adopt certain types of practical and rational conduct (Weber, 1985:26).

When these types have been obstructed by spiritual obstacles, the development of rational economic conduct has also met serious inner resistance (Weber, 1986:26,27).

And it is, among others, the ethical ideas of duty, based on religious forces, which "have in the past always been among the most important formative influences on conduct" (Weber, 1985:27).

\section{THE WORK ETHIC AS A CONSTANT VALUE}

The work ethic is a moral belief with a very strong influence going back centuries. The Protestant work ethic has aroused a fluidity of activeness and by that a propensity to efficiency that the best words can never achieve, even under changing conditions, because this moral belief started to develop on its own as soon as the religious substratum lost its importance for the people. This means that the Protestant work ethic has become a constant and nearly timeless value, although the religious com- 
ponents of the formula of economic and social success are visibly diminishing. This can be seen in Germany. The work ethic has become a durable value, even alive when the pursuit of its orientation is deprived of religious belief.

One can say that the more rural life is, the more religious belief will be tenable, and that urban life and modern industrialization diminish the incentive given by the Protestant work ethic. The colours of work ethic grow pale so that even a strong market-oriented policy has a lot of difficulty revitalizing the market forces.

It will be remembered that the first industrial revolution started in Britain and Britain was the origin of capitalism. One look at this country will, however, clearly illustrate that the situation today has drastically changed since then.

The French legal and political philosopher, Montesquieu, in his famous work Esprit de lois saw the secret of British power in the early days in the formula of success which he defined: "The English", he said, "had progressed the farthest of all the people in the world in three important things: in religious values, in commerce, and in freedom."

The work ethic is a system creating 'core-configuration' forming together with the civil liberties and freedom of trade the framework of a democratic and social state, based on a free market economy.

There is no need to say here that there is a very close connection between the political and the economic orders, which means that personal and political freedom can only be realized in a free market system. Furthermore the maximum creativity a human being is able to achieve can only be realized in a system which guarantees freedom and free competition.

The work ethic therefore is the alpha and the omega for an understanding of whom economic and social success can be ascribed to. This is because the world-wide victory of the free market system can be attributed to three main components of achievement: diligence, individual freedom and economic freedom. In other words, careful and conscientious hard work, the right to the free development of everyone's personality and a competitive market system (competitive economy) together form one unity. 


\section{THE PROTESTANT ETHIC AS A BASIC ELEMENT OF THE SPIRIT OF CAPITALISM}

Let us look at the religious elements of the spirit of capitalism, basic values which meanwhile act on their own, separated from the religious substratum. The following details will help to answer the question why capital assets and leading entrepreneurial positions in Western societies were predominantly to be found in Protestant families. There are five aspects to be taken into consideration (Dahm, 1982:500):

- Luther's conception of the calling (der Lutherische Benufsbegriff)

- the Calvinist doctrine of predestination (der Calvinistische Prädestinationsglaube)

- methodical, systematic control of one's way of life (die methodische Kontrolle der Lebensführung)

- worldly-minded asceticism

- (die innerwelliche Askese) and

- the new spirit of capitalism, separated from religious roots which is creative and sclf-acting. (die weiterwirkende Kraft der Sinikturen, die den Geist des Kapitalismus heute pragen).

These aspects can be explained by beginning with the Lutheran conception of the calling which is described in detail by Max Weber. It reads as follows: "The conception of money-making as an end in itself to which people are bound, as a calling, was contrary to the ethical feelings of whole epochs" which "is hardly necessary to prove" (Weber, 1985:73). And Weber continues: "Now it is unmistakable that even in the German word 'Beruf, and perhaps still more clearly in the English 'calling', a religious conception, that of a task set by God, is at least suggested" (Weber, 1985:79). According to Max Weber "( $t$ )he conception of the calling in the religious sense for worldly conduct was susceptible to quite different interpretations". This means that "the effect of the Reformation as such was only that, as compared with the Catholic attitude, the moral emphasis on and the religious sanction of organized wordly labour in calling was mightily increased" (Weber, 1985:83). In this respect it would be of great value to reveal the similarity to the apprenticeship which is also a unique, a typical German way of educating young people and training them for an occupation.

Back to Max Weber: "The way in which the concept of the calling, which expressed this change, should develop further depended upon religious evolution which now took place in the different Protestant churches" (Weber, 1985:83). In the words of a layman: 
Luther considered a life of occupational fulfilment a divine service. As far as calling is concerned, this was just as if one had received a call from God relating to the mission of making work one's business.

The second aspect within this context of the basic elements of the spirit of enterprise is that of the Calvinist doctrine of predestination. Here I can only very briefly sketch the question of how this doctrine originated and how it fitted into the framework of both the Calvinist theology and the Protestant work ethic.

"Calvinism was the faith over which the great political and cultural struggles of the sixteenth and seventeenth centuries were fought" (Weber, 1985:98) and this was in the most highly developed countries in Europe: in the Netherlands, in England, in France and in the German dukedoms as well. At that time, and in general even today, the doctrine of predestination was considered its most characteristic dogma (Weber, 1985:98). Here Max Weber refers to the Westminster Confession of 1647 - one of the great synods of the 17th century - where one reads in chapter III: "By the decree of God for the manifestation of His glory, some men and angels are predestinated unto everlasting life, and others fore-ordained to everlasting death" (Weber, 1985:100). Historically the doctrine of predestination was the starting point of the ascetic movement, usually known as pietism.

By reducing this complicated theological thoughts into rules for practical use, the idea was formed to the syllogism practicus, that is to say that the blessings of God can be measured by successful lifestyle, good health, by showing great personal energy and enthusiasm and prosperity. This explanation later led to economic and social dynamism, because all Protestant Christians who were concerned about their salvation started to receive the blessings of God by obeying a way of life to the best of their ability, especially making sure to follow the principles of life in order to gain an everlasting life or at least to reduce the unpleasant feeling that they probably would belong to the group of people being fore-ordained to everlasting death.

Methodical control of one's lifestyle, the third aspect, means sharing divine grace by the fair means of hard work in an honest trade. Control of one's lifestyle gradually became a habit starting with economical house-keeping and later leading to accountancy, both of which were evolved from these attitudes of the systematic control of life.

This basic rationality is a constitutive pillar of modern life only as far as the countries of Europe and North America are concerned and some other regions where Europeans 
have settled, also in South Africa of course. That makes the great difference to countries based on other cultural patterns. And it was only due to the grounds of this basic rationality that the spirit of capitalism could develop.

The fourth aspect, worldly-minded asceticism, is the foundation stone of a way of life that is simple and strict and in which the subjects themselves feel bound to follow a strenuous ascetic work discipline. This discipline implies living within this world and not out of it, like a monk in a monastery. This approach also means that one voluntarily does without the luxuries of life, like alcohol, dancing, entertainment, etc.; one lives purely for one's family and work.

Meanwhile the spirit of capitalism has changed its face, insofar as we can speak of a free market economy with a work ethic and with economic attitudes which are quite typical for capitalism. These economic attitudes are religious motivation, but with a new structure of industrial relation. Instead of worldly-minded ascetism we now find business sense based on the acquisitive principle, no longer conscious of any religious content.

As has already been mentioned, in certain regions of Europe characteristics of socioeconomic structures are formed by the combination of Calvinist-influenced piety and the spirit of capitalism. The spirit of capitalism means the ability to think of new and effective combinations of production factors in conjunction with an eagerness to use them. Applied to an everyday situation: the good profits a Calvinist-capitalist entrepreneur makes by the work he and his workers do very diligently can sometimes not be spent because of a strenuous way of living. The fact that profits are not spent, results in re-investment in the business and consequently the assets are increased.

The development of the spirit of capitalism has various stages.

- The first stage: the fear of being expelled from the grace of God for not showing diligence.

- The second stage: control (supervision) of one's way of life motivated by the fear of God. Sharing divine grace by the fair means of hard work in an honest trade was seen as being essential to one's way of life.

- The third stage: From this controlled lifestyle arose a private sector mentality - a work ethic - to do hard work and to subject oneself to a strenuous ascetic discipline. 
* The fourth and last stage: A new type of spirit of capitalism which is more or less separated from religious roots, self-acting as a secularized spirit of capitalism. This spirit of capitalism can also be regarded as the laicized type of free market system.

\section{THE PROTESTANT ETHIC AND THE SIEGERLAND MENTALITY}

Even if the religious element has to a certain extent lost its attraction in the course of time, the ethical ideas of duty are still alive today. The geographical region which is very well known for its people still influenced by Calvinist attitudes of mind is the Siegerland. That is why experts speak of the Siegerland mentality when explaining the phenomenon of work ethic within the context of the Protestant ethic and the spirit of capitalism. Here we come closest to the fascinating source to gain specific insight into the development of an economic spirit which means the roots to the ethos of an economic system.

In our case we are dealing with a connection of the spirit of modern economic life with the rational ethics of ascetic Protestantism (Weber, 1985:27). The Siegerland mentality has quite a number of elements of great pro-social strength which result in social-mindedness and by this means, in social peace. This means that the majority of workers did not see and still do not see a class enemy in their entrepreneur. Worker and entrepreneur have no sense of social conflict or even confrontation. What they feel for each other is a more overlapping social mutuality, knowing that the common interests are much stronger than the social differences. That is the case because the belong to the same church and have the same faith which reduces the natural tension between the entrepreneur and his personnel.

This typical mutuality had been influenced, or rather properly speaking, had been contributed to by the certitude that economic success had something to do with the full blessing of the Lord and this can only be achieved by a way of life which presupposes putting one's trust in the Lord: hard work brings its own reward. This general tendency of social conduct in the Siegerland exercised an influence upon politics, especially before and after World War I. The socio-economic atmosphere therefore was detcrmined by an expression, namely christlich-sozial.

This combination of Christian and social aspects gives expression to the link between eternity and the progress of time on earth. In other words: Christian stands for eternity and social stands for contemporaneity. 
Within the Siegerland mentality, the keynote of the Christian-social obviously had the function of acting according to the divine law to see in charity the first principle for everyone's actions which also means that charity is a standard in social life. The more people applied this principle to their own lives, the less the ideas of social reformers had any chance of attracting attention.

In a broader sense, the Christian-social is a keynote which, politically speaking, indeed worked as a stabilizing factor in West Germany. May I recall for you that after World War II the Christian Social Union in Bavaria and the Christian Democratic Union in the other parts of the Federal Republic of Germany undoubtedly paved the way for 40 years of economic success on the basis of the social market economy.

What are the characteristic features of the Siegerland mentality in particular? The German sociologist of religion, Karl Wilhelm Dahm (Dahm, 1982:500), sees four prominent features:

1. To make activity and dynamics a matter of principle.

2. An anti-worldly-minded and strict lifestyle.

3. A consciousness of exclusiveness.

4. An anti-authoritarian sense of solidarity.

What do these characteristic features of the Siegerland mentality actually mean?

The first feature defining property does not need any clarification, because it expresses the typical activistic feature of economic behaviour in the Siegerland at a glance. An old saying expresses this mentality: 'Bring something into being, be active, be economical and save money, build a house and die as a Christian'.

The second characteristic is also clear, because it reveals the prime necessity (the first principle of action): to observe the commandments of God and to apply strong moral standards in life, i.e. both in private en business life. Gathering vast wealth is of secondary importance, because the essence of life is to withstand the supreme tests of everyday life, and life is nothing but work. That is the dictate of reason: one's whole life is a challenge.

The third characteristic feature means that the indigenous people of the Siegerland feel unique as far as their cultural traditions are concerned. This belief in the self has led to the unmistakable consciousness of originality. The Siegerländer feels himself different in his habits from people in other regions of Germany. 
The final but not least characteristic is to be seen in the anti-authoritarian sense of solidarity which is to be found in a basic attitude following the principle of communal living with religious affiliation in a Presbyterian-democratic style. The antiauthoritarian aspect could be seen as being disinclined vis-à-vis any ecclesiastical authority, and in a loathing for an official church with pastors and an ecclesiastical bureaucracy. While the principle of activity and the anti-worldly-mindedness, following the principle of strict conduct of life, helps us to a better understanding of Max Weber's concepts of the Protestant ethic, the last two characteristics, the consciousness of exclusiveness and the anti-authoritarian sense of solidarity, are conducive to the understanding of the very special nature of the Siegerland mentality 2 (Dahm, 1982:491).

\section{Conclusion}

What strikes one about the whole matter is the unique combination of pietistic religiousness and the striving for economic performance which means economic efficiency as well.

It is true that the image of the Siegerland mentality has in the meantime been blurred as a result of the remarkable influx of people who at the end of and after World War II came as refugees, and persons who resettled from the eastern parts of Germany or from Poland or Czechoslovakia.

The University of Siegen also contributes to this migration movement. Despite the change of attitudes, running parallel with the loosening of morals, the vital functions of the Siegerland mentality, however, have stayed alive.

This unique mentality, combined with a relative measure of seclusion, is the reason for the fact that quite a number of entrepreneurs have, step by step, lost touch with technological progress. For that reason they have come into conflict with the new entrepreneurial concepts and with the - ever-accelerating - speed of change now current in our age of highly sophisticated technology and information. Some of these

\footnotetext{
${ }^{2}$ Recommendation for further reading:

Jenkins, Helmut W. 1980. Leistung - ein inhumaner Anspruch? Zum Ursprung und zur Kritik des Leistungsprinzips. (Performance - an inhuman demand? Origin and critique of the performance principle). Frankfurt on Main.

Poggi, Gianfranco 1983. Calvinism and the capitalist spirit. Max Weber's Protestant ethic.

London et al.
} 
entrepreneurs became so remote that they lost their international competitiveness and were replaced by more creative managers, who believe in the future potential of the world market and who cast a glance over the fence of their own region or even country, and who move with the times because they see that it is about time to go international, based on a modern concept of competitive management and technology.

But this, of course, leads to a further erosion of religious elements in the philosophy of the firms and it affects the managerial policy - without any doubt. Small and mediumsized enterprises have found a complement in larger companies coming into this region and by capital flow from outside.

I come to the conclusion that it is not socialism that is the challenge now or in times to come. Socialist ideas have undoubtedly failed to have any practicability because they have proven to be unsuccessful wherever they have been applied. It is still the free market mechanism which has proved its efficacy and which during changing times has to be kept at the peak of its potentiality. The modern free market system, once born from the ideas giving rise to the spirit of capitalism, based on the acquisitive principle and the principle of social responsibility, led to new industrial relations by which the spirit of capitalism was converted into the spirit of free enterprise. We can also speak of a social market economy which has become the first and constitutive principle for any modern westernized industrialized country.

\section{BIBLIOGRAPHY}

BRINKMAN, Richard 1981. Cultural Economics. Portland : Oregon.

DAHM, Karl-Wilhelm 1982. Siegerland Mentalität und Max-Weber These. (In Gemper, Bodo B. ed. Religion und Verantwortung als Elemente gesellschaftlicher Ordnung. (Religion and responsibility as elements of a stable society.) Siegen. p. 500.)

SAMUELSON Paul A. \& NORDHAUS, William D. 1985. Economics, 11th ed. New York.

WEBER, Max 1985. The Protestant ethic and the spirit of capitalism (translated by Talcott Parsons). London. 